\title{
STRUCTURAL CHANGES IN LAND USE OF AGRICULTURAL HOLDINGS IN HILLY RURAL AREAS
}

SPREMEMBE V STRUKTURI UPORABE ZEMLJIŠČ NA KMEČKIH GOSPODARSTVIH NA HRIBOVITIH PODEŽELSKIH OBMOČJIH

Kristina Knific, Štefan Bojnec

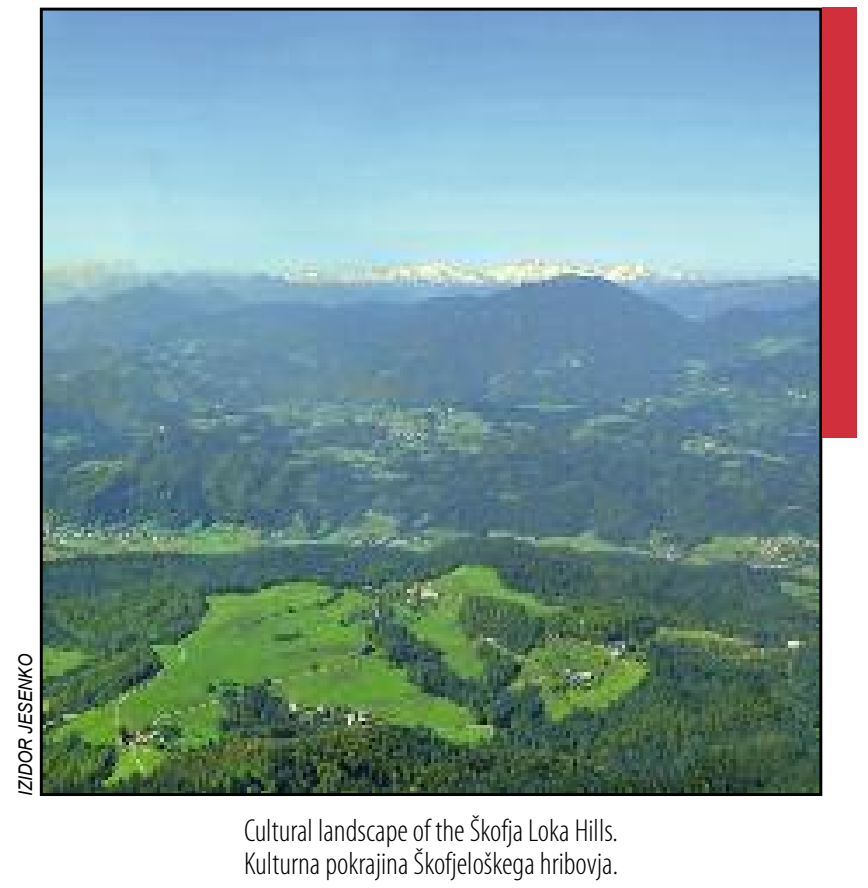




\section{Structural changes in land use of agricultural holdings in hilly rural areas}

DOI: http://dx.doi.org/10.3986/AGS.736

UDC: $338.43: 332.21(497.4)$

COBISS: 1.01

ABSTRACT: This paper analyses structural changes in agricultural holdings in the Škofja Loka region focusing on land use in the years 2000 and 2010. The analysis is conducted for the Škofja Loka region by socio-economic types of agricultural holdings, and by territories with different levels of economic development and different natural factors for agricultural production. Structural changes are different between municipalities with different natural factors for agricultural production and different levels of economic development as well as socio-economic types of agricultural holdings. State support for agricultural activity has mitigated overgrowth of agricultural land on naturally less favoured territories.

KEY WORDS: geography, structural changes, agricultural activity, agricultural holding, hilly areas, Slovenia

The article was submitted for publication on August $6^{\text {th }}, 2013$.

\section{ADDRESSES:}

Kristina Knific, Ph.D.

Municipality Gorenja vas-Poljane

Poljanska cesta 87, SI - 4224 Gorenja vas, Slovenia

E-mail: kristina.knific@obcina-gvp.si

Štefan Bojnec, Ph.D.

University of Primorska

Faculty of Management

Cankarjeva ulica 5, SI - 6104 Koper, Slovenia

E-mail: stefan.bojnec@fm-kp.si 


\section{Introduction}

Over the last two decades, the agricultural research conducted in the transition countries of Central and Eastern Europe has often been related to land reforms, policies and agricultural land markets (e.g. Csaki and Lerman 2000; Bojnec 2013). In Slovenia, agricultural holdings comprise the greatest part of rural areas: as much as $96 \%$ of the land (Dernulc et al. 2002; Razpotnik Visković 2011). Their role in rural areas is multifunctional and includes the production of sufficient quantities of quality food, social role (above all the preservation of settlements, cultural and natural heritage, quality of life in rural areas and balanced spatial development) and also an environmental role (above all the protection of water resources, biodiversity conservation and climate changes; van Huylenbroeck et al. 2007). The competitiveness of Slovenian agriculture is low due to unfavourable size (dominance of small and medium-sized farms) and the socio-economic and production structure of farms (Cunder 1997; Vešter 2005). The production structure is limited due to the low production potential in the less-favoured areas for agricultural production which cover $85 \%$ of Slovenian territory, of which slightly less than $72 \%$ are hill and mountain areas (Republic of Slovenia 2009). The existence of agricultural activity of agricultural holdings in these areas depends on the State's support (e.g. Knific and Bojnec 2009; 2010; Slabe-Erker 2005) and provides the basis for the development of other economic activities in rural areas (Flury, Giuliani and Buchli 2008), being simultaneously oriented towards sustainable forms of agricultural production and the development of supplementary activities on farms (Bojnec, Jurinčič and Vodeb 2007; Korošec 2007; Kladnik 1999; Klemenčičc, Lampič and Potočnik Slavič 2009). With the accession to the European Union (EU), Slovenia adopted its policies, among which common agricultural policy and rural development policy are the most important in view of agricultural activity. The EU Financial Perspective 2007-2013 allocated a little less than $42 \%$ of the EU budget to support agriculture and its role in rural development (European Parliament 2008).

The speed and the direction of change depend on the policy objectives and measures implemented (Happe 2004); however, not all agricultural holdings respond in the same way (Wolek 2009).

In order to maintain the cultivation of agricultural land in marginal areas, non-production related support is introduced by agricultural policy (Happe 2004; Brady et al. 2009; Kropp and Whitaker 2011).

This paper presents the results of the analysis of structural changes in land management in agricultural holdings of the Škofja Loka region with emphasis on the differences between 2000 (three years before Slovenia's accession to the EU) and 2010. In 2000, the rules of the common market were established in Slovenia, the state's support was mostly production related and the implementation of pre-accession assistance (SAPARD measures) began. After Slovenia's accession to the EU in 2004, non-production related payments were gradually established.

The analysis was conducted on three samples and sub-samples of agricultural holdings, namely: the sample of all agricultural holdings in the Škofja Loka region and sub-samples in view of communities or municipalities with different natural resources for agricultural production and economic development as well as by socio-economic types of agricultural holdings.

The research is focused on:

- the municipality of Škofja Loka, which is economically developed with relatively favourable conditions for agriculture as it covers the area of »Sorško polje« and

- the economically less developed municipality Gorenja vas-Poljane with a greater distance from city centres (local markets), with poorer conditions for agricultural production.

The research by municipalities or communities allowed the detection of changes and differences in the direction and size of the land under the management of agricultural holdings also in the cases when they cannot be detected by researching the sample of all agricultural holdings in the Škofja Loka region. In addition, research by socio-economic types of agricultural holdings allows the detection of changes and differences in the direction and size of the land under the management of a particular socio-economic type of agricultural holding, reflecting the importance of agricultural activity of AHs for its survival (Kovačič 1996; Frenkel and Rosner 1999; Wolek 2009).

\section{Method}

An agricultural holding is defined as a household with a farm, which complies with the criteria of a comparable farm in Europe. In the frame of this research, we classified socio-economic types of farms after 
Kovačič (1996) with a variation: due to our noticing the significance of a supplementary activity on a farm we subdivide mixed and supplementary farms into mixed farms, supplementary farms and aged farms/farms in abandonment. The data on the land areas managed by agricultural holdings in the Škofja Loka region were collected for the population of AHs during the state's statistical censuses registering of farms (agriculture) in the years 2000 and 2010 (Dernulc et al. 2002; SORS 2010). The analyses of the changes in arithmetic means of the area of the land managed by agricultural holdings in the years 2000 and 2010 or between the two municipalities by socio-economic types of agricultural holdings are conducted by means of a t-test and the programme Statistical Package for the Social Sciences. The acceptable level of risk amounts to 5\%. We define the socio-economic type of AH population based on (like Kovačič 1996 and Udovič, Kovačič and Kramarič 2006) the employment status of the agricultural holding core. Land in agricultural holding managing is all the land used by an agricultural holding and is divided into forest, infertile land and agricultural land. Agricultural land includes agricultural land in use, overgrown agricultural land or such land in the process of becoming overgrown and other uncultivated agricultural land. Agricultural land in use includes private and hired agricultural land in use and is further subdivided into fields and gardens, orchards, vineyards, and meadows and pastures (Dernulc et al. 2002).

\section{Results}

In the Škofja Loka region the number of agricultural holdings decreased by $7 \%$ in the period between 2000 and 2010, which is two times less than the average for agricultural holdings in the Republic of Slovenia, which decreased by 14\%; Kutin Slatnar et al. 2012) and more than three times less than the EU average, which decreased by $27 \%$ or by $19.8 \%$, excluding Malta for the period 2003-2010 (Eurostat 2011). The decrease in the number of agricultural holdings between 2000 and 2010 differs in the municipality of Škofja Loka (-9\%) and the community of Gorenja vas-Poljane $(-5 \%)$. The number of commercial farms (pure, mixed and supplementary farms) slightly increased in the municipality of Škofja Loka $(+4 \%)$ and decreased in the community of Gorenja vas-Poljane $(-4 \%)$. The number of supplementary farms increased, while the number of mixed farms and farms in abandonment decreased (Table 1). Farms in abandonment exit the sector twice as fast in the area of the municipality of Škofja Loka than in the area of the community of Gorenja vas-Poljane.

Most of the land in the region of Škofja Loka is managed by agricultural holdings. In 2000, agricultural holdings composed $69 \%$ of the surface area in the municipality of Škofja Loka and in community Gorenja vas-Poljane they composed $66 \%$ in 2010 . The average area managed by agricultural holdings was 19.2 ha, of which slightly over $61 \%$ was forest ( $12 \mathrm{ha}), 38 \%$ agricultural land ( $7.31 \mathrm{ha})$ and $0.9 \%(0.17 \mathrm{ha})$ infertile agricultural land. Between 2000 and 2010, the area of infertile land reduced statistically significantly in agricultural holding population, in agricultural holdings by municipalities or communities and in all socio-economic types except mixed farms.

\subsection{Forest area managed by agricultural holdings}

In 2010 agricultural holdings composed $122 \mathrm{~km}^{2}$ of forest, while in 2000 they composed slightly over $3 \%$ less. In comparison to 2000, the average forest area in agricultural holdings in 2010 statistically significantly increased in supplementary farms, while it decreased in pure and mixed farms and in farms in abandonment (Table 1).

\subsection{Agricultural land}

In the year 2000, agricultural holdings composed slightly less than 7.2 ha of agricultural land on average, which is by one fifth higher than the average value of AHs in Slovenia (5.9 ha; Dernulc et al. 2002). The total area of agricultural land in use decreased by $7 \%$ in agricultural holdings in the Škofja Loka region between the years 2000 and 2010, due to, above all, the reduction of the area managed by the farms in abandonment and aged farms ( $-657 \mathrm{ha})$; however, with commercial farms it increased $(+289 \mathrm{ha})$. The average area of agricultural land of agricultural holdings increased statistically significantly just with the agricultural holdings in the municipality of Škofja Loka, due to, above all, abandonment of agricultural production with 


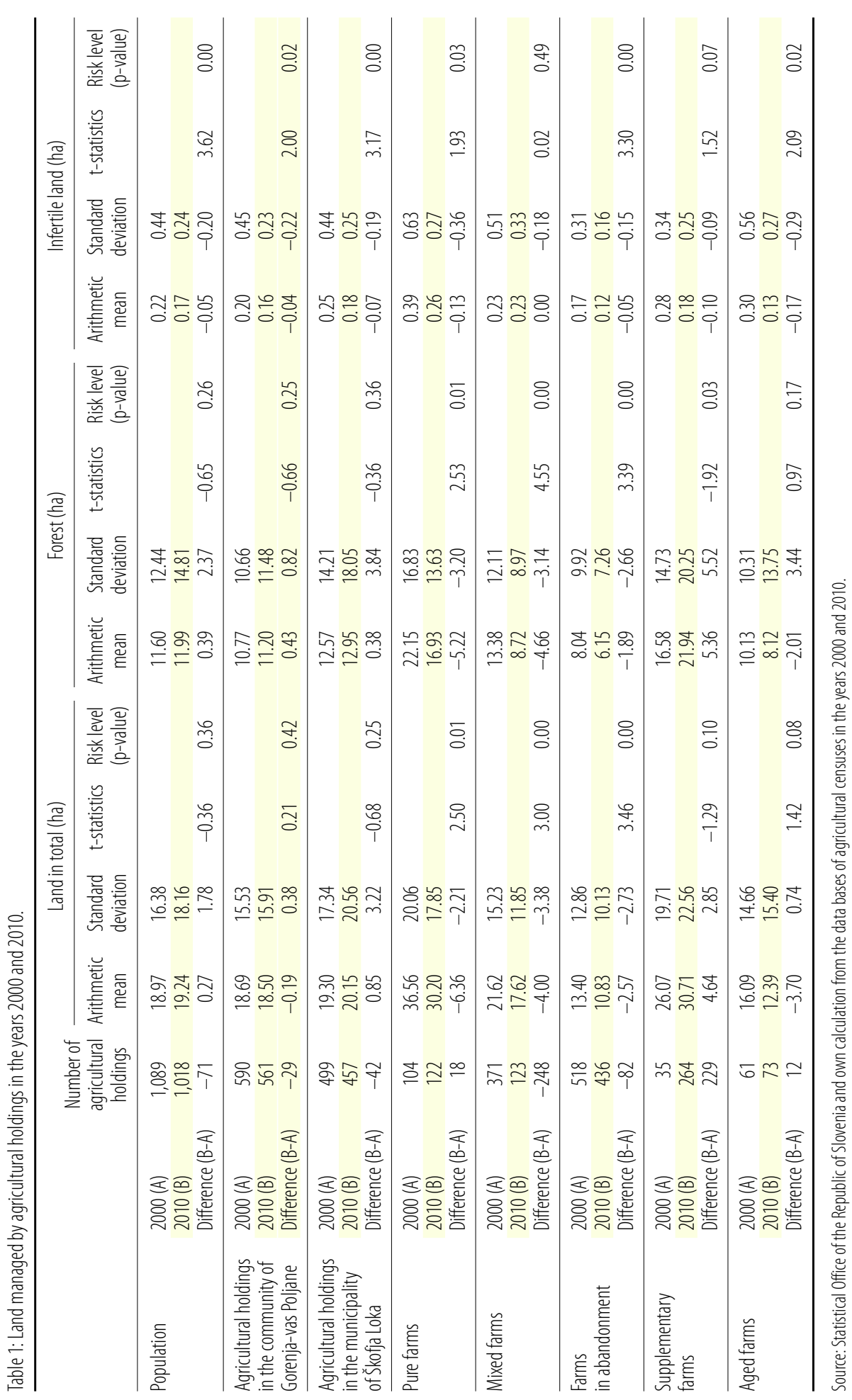




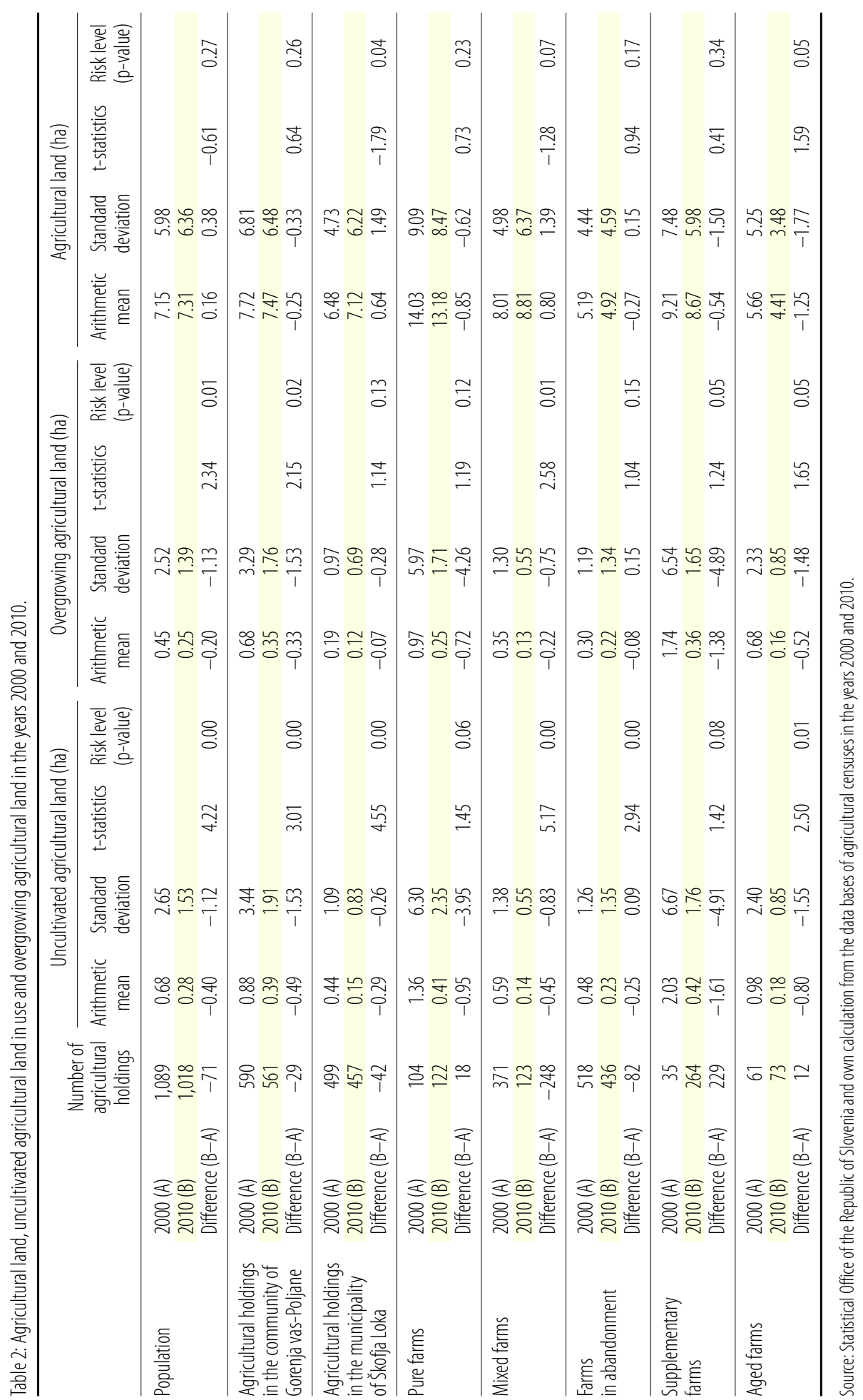




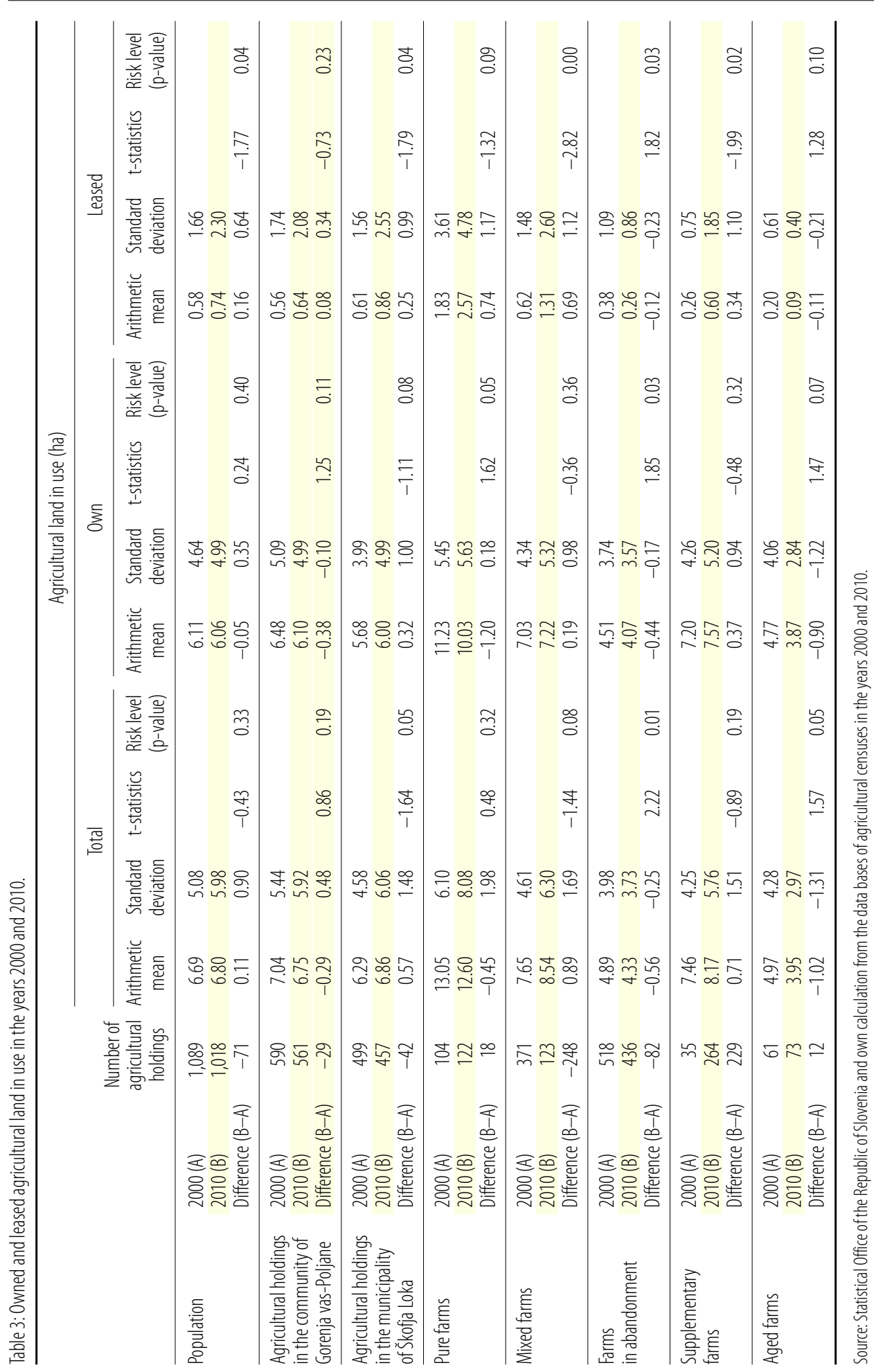


the farms in abandonment (abandonment of agricultural production) and the reduction of the area in the aged farms (Table 2).

Overgrowing agricultural land amounted to $6.8 \%$ of all agricultural land managed by agricultural holdings or 0.45 ha per agricultural holding in the year 2000, which is 1.3 times less than the Slovenian average (Dernulc et al. 2002); however, in the year 2010 its average area almost halved. The average area of overgrowing agricultural land decreased statistically significantly with agricultural holdings, with mixed and supplementary farms as well as with aged farms, in the community of Gorenja vas-Poljane (Table 2). This is due to the state's support related to the units of area payments.

The percentage of infertile land managed by agricultural holdings was lower in 2010 than in 2000 with the population of agricultural holdings by municipalities and by socio-economic types, with the exception of mixed farms (Table 2).

The average area of agricultural land in use totalled 6.7 ha per agricultural holding in the year 2000, which is slightly more than $13 \%$ higher than the Slovenian average (5.9 ha; Dernulc et al. 2002). During the years 2000 and 2010, the average area of agricultural land in use increased statistically significantly by $10 \%$ in agricultural holdings in the municipality of Škofja Loka, due to, above all, abandonment of agricultural production on farms in abandonment and the reduction in the area of agricultural land in use with aged farms and farms in abandonment (Table 3). A greater average area of the leased agricultural land in use with the population of AHs in the year 2010, compared to the year 2000, resulted from a bigger area of the leased agricultural land in use with agricultural holdings in the municipality of Škofja Loka or a greater area of the leased agricultural land in use of commercial farms; however, the average leased area of agricultural land in use decreased with non-commercial farms (Table 3). Agricultural holdings in the municipality of Škofja Loka composed almost 6 times greater an area of fields (1.8 ha/agricultural holding), and agricultural holdings in the community Gorenja vas-Poljane composed a fourth bigger area of permanent meadows and pastures.

During the years 2000 and 2010 there were changes in agricultural holdings in the area of agricultural land in uses by the agricultural land in use classes in the polarization of the growth in the size of agricultural holdings by the area of agricultural land in use in two directions: a group of relatively big commercial farms (agricultural land in use above $15 \mathrm{ha}$ ) and a group of smaller farms (agricultural land in use 3-5ha). The reasons are ascribed, beside the abandoning of agricultural production on smaller farms in terms of the area of agricultural land in use, to the maintaining of agricultural production on particular small farms that are predominantly self-reliant (3-5 ha of agricultural land in use) and to the increase in farm sizes and taking advantage of the economy of scale with the rest of the farms in the direction of bigger farms by the area of agricultural land in use (above 15 ha of agricultural land in use). The polarisation is a bit more explicit with agricultural holdings in the municipality of Škofja Loka.

\section{Conclusion}

Most of the land in the Škofja Loka region was managed by agricultural holdings in the years 2000 and 2010 . The average area of agricultural holding land (forest, agricultural land and infertile land) in the Škofja Loka region increased statistically insignificantly; however, the total area of land managed by agricultural holdings decreased, above all due to the decreasing of the area of the land managed by farms in abandonment (small, mainly self-reliant farms). The number of farms in abandonment and mixed farms decreased; however, the number of supplementary farms increased. For their survival, forest with wood processing as a supplementary activity on a farm was important for some supplementary farms between the years 2000 and 2010. The changes were more significant in the area with a more developed industry and better natural conditions for agricultural production. The number of pure farms is seemingly stable, above all due to the retirement of pure farmers and farmers with non-agricultural jobs.

Between the years 2000 and 2010, the structural changes in agricultural holdings with different natural conditions for farming and economic development differ in the direction and the scope of these changes. In the area with limited chances for agricultural production, the state's support relating to the area of agricultural land in use prevented the overgrowing of agricultural land; moreover, the area of infertile land decreased and the area of uncultivated agricultural land decreased in both studied areas and including all socio-economic types. The structural changes which are reflected in the abandonment of farming by 
small-scale farms and in increasing the farming areas with the rest (above all leasing agricultural land in use) are relatively slower than those of the Slovenian average and more explicit with agricultural holdings in the area with better natural conditions for farming. We can perceive the polarisation in the growth of the area of agricultural holdings by the area of agricultural land in use, in two directions: a group of relatively big commercial farms (agricultural land in use above $15 \mathrm{ha}$ ) and a group of smaller, mainly self-reliant farms (agricultural land in use 3-5 ha). The increase in the area of agricultural land in use results, above all, from a bigger area of the leased agricultural land in use with commercial farms; however, the area of their own agricultural land in use did not increase.

\section{References}

Bojnec, Š. 2013: Land endowments and land market policies in Croatia, FYR of Macedonia and Turkey. Bulgarian journal of agricultural science 19-3.

Bojnec, Š., Jurinčič, I., Vodeb, K. 2007: Razvojne možnosti trajnostnega razvoja turizma na podeželskih območjih v Istri. Slovensko kmetijsko podeželje v Evropi, ki se širi in spreminja. Ljubljana.

Brady, M., Kellermann, K., Sahrbacher, C., Jelinek, L. 2009: Impacts of decoupled agricultural support on farm structure, biodiversity and landscape mosaic, some EU results. Journal of agricultural economica 60-3. DOI: http://dx.doi.org/10.1111/j.1477-9552.2009.00216.x

Csaki, C., Lerman, Z. 2000: Structural change in the farming sectors in Central and Eastern Europe. Washington, D.C.

Cunder, T. 1997: Naravne danosti in socio-ekonomska struktura. Slovensko kmetijstvo in Evropska unija. Ljubljana.

Dernulc, S., Iljaš, U., Kutin, B., Orešenik, I., Cunder, T., Golež, M., Juvančič, L. 2002: Popis kmetijskih gospodarstev, Slovenija 2000. Ljubljana.

European Parliament. 2008: Financing of the CAP. Internet: http://circa.europa.eu/irc/opoce/fact_sheets/ info/data/policies/agriculture/article_7213_en.htm (29.7.2013).

Eurostat. 2011: EU-agricultural census 2010 - first results. Internet: Http://europa.eu/rapid/press-release_ STAT-11-147_en.htm (29.10.2012).

Flury, C., Giuliani G., Buchli, S. 2008: Evaluation of jointness between agriculture and rural development. Multifunctionality in agriculture, evaluating the degree of jointness, policy implications. Paris.

Frenkel, I., in Rosner, A. 1999: Prospects for change in the employment structure of the rural population. Village and agriculture 2.

Happe, K. 2004: Agricultural policies and farm structures: agent-based modelling and application to EU-policy reform. Halle (Saale).

Kladnik, D. 1999: Leksikon geografije podeželja. Ljubljana.

Klemenčič, M. M., Lampič B., Potočnik Slavič, I. 2008. Življenjska (ne)moč obrobnih podeželskih območij v Sloveniji. Ljubljana.

Knific, K., Bojnec, Š. 2009: Diverzifikacija dohodkov gospodinjstev na hribovitem podeželskem območju. Koper.

Knific, K., Bojnec, Š. 2010: Agricultural households in mountain areas in pre- and post-accession Slovenia. Journal for Geography 5-1.

Korošec, V. 2007: Podeželski turizem v spodnjem Podravju in regijska turistična ponudba. Geografski vestnik 79-2.

Kovačič, M. 1996: Socio-ekonomska in velikostna struktura kmetij v Sloveniji v obdobju 1981-1991. Ljubljana. Kropp, J.D., Whitaker, J. B. 2011: The impact of decoupled payments on the cost of operating capital. Agricultural finance review 71-1.

Kutin-Slatnar, B., Krajnc, A., Lojović Hadžihasanović, E., Stele, A. 2012: Popis kmetijstva, 2010. Ljubljana.

Razpotnik Visković, N. 2011: Vpliv stopnje urbaniziranosti na dohodkovne vire družinskih kmetij v Sloveniji. Geografski vestnik 83-1.

Republic of Slovenia, 2009: Nacionalni strateški načrt razvoja podeželja, 1. sprememba. Ljubljana.

Slabe Erker, R. 2005: Ekonomsko vrednotenje neblagovnih učinkov. Slovenija v EU, izzivi za kmetijstvo, živilstvo in podeželje. Ljubljana. 
Statistical Office of the Republic of Slovenia, 2000: Bazi podatkov popis kmetijstva v letu 2000, Občina Škofja Loka in občina Gorenja vas-Poljane. Poslovni dokumenti, Statistični urad Republike Slovenije. Ljubljana.

Statistical Office of the Republic of Slovenia, 2010: Bazi podatkov popis kmetijstva v letu 2010, Občina Škofja Loka in občina Gorenja vas-Poljane. Poslovni dokumenti, Statistični urad Republike Slovenije. Ljubljana.

Udovič, A., Kovačič M., Kramarič, F. 2006: Socio-ekonomski tipi kmetij po podatkih popisa kmetijskih gospodarstev v letu 2000. Slovenija v EU, izzivi za kmetijstvo, živilstvo in podeželje. Ljubljana.

Van Huylenbroeck, G., Vandermeulen, V., Mettepenningen, E., Verspecht, A. 2007: Multifunctionality of agriculture: A review of definitions, evidence and instruments. Living reviews in landscape research 1-3. DOI: http://dx.doi.org/10.12942/lrlr-2007-3

Vešter, I. 2005: Velikost kmetijskih gospodarstev v Sloveniji. Geografski vestnik 7-1.

Wolek, T. 2009: Can we really talk about structural change? The issue of small-scale farms in rural Poland. Structural change in Europe's rural regions, farm livelihoods between subsistence orientation, modernization and non-farm diversification. Halle (Salle). 



\section{Spremembe v strukturi uporabe zemljišč na kmečkih gospodarstvih na hribovitih podeželskih območjih}

DOI: http://dx.doi.org/10.3986/AGS.736

UDK: 338.43:332.21(497.4)

COBISS: 1.01

IZVLEČEK: V prispevku so analizirane strukturne spremembe na kmečkih gospodarstvih na škofjeloškem območju s poudarkom na empirični analizi zemlje v upravljanju v letih 2000 in 2010 . Analiza je izvedena za škofjeloško območje, po socio-ekonomskih tipih kmečkih gospodarstev in po območjih z različno gospodarsko razvitostjo in različnimi danostmi za kmetijsko pridelavo. Strukturne spremembe zemlje na škofjeloškem območju so za obdobje 2000-2010 potrjene in so med občinama z različnimi naravnimi danostmi za kmetijko pridelavo in gospodarsko razvitostjo različne, prav tako so zaznane razlike po socio-ekonomskih tipih kmečkih gospodarstev. Državne pomoči kmetijski dejavnosti so preprečile zaraščanje kmetijske zemlje na območju s slabšimi naravnimi danostmi.

KLJUČNE BESEDE: geografija, strukturne spremembe, kmetijska dejavnost, kmečka gospodarstva, hribovito območje, Slovenija

Uredništvo je prejelo prispevek 6. avgusta 2013.

NASLOVA:

dr. Kristina Knific

Občina Gorenja vas-Poljane

Poljanska cesta 87, SI - 4224 Gorenja vas, Slovenija

E-pošta: kristina.knific@obcina-gvp.si

\section{dr. Štefan Bojnec}

Univerza na Primorskem

Fakulteta za management

Cankarjeva ulica 5, SI - 6104 Koper, Slovenija

E-pošta: stefan.bojnec@fm-kp.si 


\section{Uvod}

V zadnjih dveh desetletjih se raziskave v kmetijstvu tranzicijskih držav srednje in vzhodne Evrope pogosto navezujejo na zemljiške reforme, politiko in trge kmetijskih zemljišč (npr. Csaki in Lerman 2000; Bojnec 2013). V Slovenji so kmečka gospodarstva najpomembnejši upravljavci podeželske krajine, saj upravljajo s kar 96 \% zemljišč (Dernulc s sod. 2002; Razpotnik Visković 2011). Njihova vloga na podeželju je multifunkcionalna in obsega poleg proizvodnje zadostnih količin kakovostne hrane tudi socialno vlogo (predvsem ohranjanje poseljenosti, kulturne in naravne dediščine, kakovosti življenja na podeželju in uravnotežen prostorski razvoj) ter okoljsko vlogo (predvsem varovanje vodnih virov, ohranjanje biološke raznovrstnosti in podnebne spremembe) (van Huylenbroeck s sod. 2007). Konkurenčnost slovenskega kmetijstva je zaradi neugodne velikostne (prevlada majhnih in srednje velikih kmetij), socio-ekonomske in proizvodne strukture kmetij nizka (Cunder 1997; Vešter 2005). Proizvodna struktura je omejena predvsem zaradi nizkih proizvodnih potencialov na območjih z omejenimi možnostmi za kmetijsko pridelavo, ki pokrivajo $85 \%$ ozemlja Slovenije, od tega je nekaj manj kot $72 \%$ hribovsko gorskih območij (RS 2009). Obstanek kmetijske dejavnosti kmečkih gospodarstev na teh območjih je povezan z državno pomočjo (npr. Knific in Bojnec 2009, 2010; Slabe-Erker 2005) in daje osnovo za ekonomski razvoj drugih dejavnosti na podeželju (Flury, Giuliani in Buchli 2008) s sočasnim usmerjenjem v trajnostne oblike kmetijske pridelave in razvoj dopolnilnih dejavnosti na kmetiji (Bojnec, Jurinčič in Vodeb 2007; Korošec 2007; Kladnik 1999; Klemenčič, Lampič in Potočnik Slavič 2009). Slovenija je s pristopom k Evropski Uniji (EU) prevzela njene politike, od katerih sta $\mathrm{z}$ vidika kmetijske dejavnosti najpomembnejši skupna kmetijska politika in politika razvoja podeželja. EU je v finančni perspektivi 2007-2013 nekaj manj kot $42 \%$ proračuna EU namenila pomočem kmetijstvu in njegovi vlogi pri razvoju podeželja (European Parliament 2008). Od ciljev politik oziroma izvedenih ukrepov je odvisna hitrost in smer sprememb (Happe 2004), vendar vsa kmečka gospodarstva ne odreagirajo enako (Wolek 2009). Za ohranitev obdelanosti kmetijske zemlje na marginalnih območjih so uvedene neproizvodno vezane pomoči (Happe 2004; Brady s sod. 2009; Kropp in Whitaker 2011).

V okviru tega prispevka predstavimo rezultate analize strukturnih sprememb zemlje v upravljanju kmečkih gospodarstev na Škofjeloškem s poudarkom na ugotavljanju razlik med letoma 2000 (tri leta ped pristopom Slovenije k EU) in 2010. V letu 2000 so se v Sloveniji uveljavila pravila skupnega trga, državne pomoči so bile pretežno vezane na proizvodnjo, pričeli so se izvajati ukrepi predpristopne pomoči SAPARD. Po pristopu Slovenije k EU v letu 2004 pa so se postopoma uveljavila neproizvodno vezana plačila.

Analiza je izvedena skozi tri vzorce in pod-vzorce kmečkih gospodarstev, in sicer: za celoten vzorec kmečkih gospodarstev za škofjeloško območje, znotraj njega po občinah z različnimi naravnimi danostmi za kmetijsko pridelavo in gospodarsko razvitostjo ter po socio-ekonomskih tipih kmečkih gospodarstev. $\mathrm{Z}$ raziskavo se osredotočimo na:

- Škofjeloško območje, natančneje na občini Škofja Loka, ki je gospodarsko bolj razvito območje z relativno ugodnejšimi pogoji za kmetijstvo, ker del območja obsega Sorško polje, in

- Gorenja vas-Poljane, ki je gospodarsko slabše razvita z večjo oddaljenostjo do mestnih središč (lokalni trgi), s slabšimi pogoji za kmetijsko pridelavo, ki so relativno slabši za celotno območje občine, ki se nahaja na območju z omejenimi pogoji za kmetijsko pridelavo. Raziskava po občinah omogoči zaznavo sprememb in razlik v smeri in obsegu zemlje v upravljanju kmečkih gospodarstev tudi v primeru, ko le-te pri populaciji celotnega območja ni mogoče zaznati. Nadalje raziskava po socio-ekonomskih tipih kmečkih gospodarstev omogoči zaznati spremembe in razlike v smeri in obsegu zemlje v upravljanju posameznega socio-ekonomskega tipa kmečkih gospodarstev, ki odraža pomen kmetijske dejavnosti kmečkih gospodarstev za njegovo preživetje (Kovačič 1996; Frenkel in Rosner 1999; Wolek 2009).

\section{Metoda}

Kmečka gospodarstva so gospodinjstva s kmetijo, ki izpolnjuje kriterije evropsko primerljive kmetije. V okviru te raziskave določamo socio-ekonomske tipe kmečkih gospodarstev po Kovačiču (1996) s to razliko, da zaradi zaznave pomena dopolnilne dejavnosti na kmetiji razdelimo mešane in dopolnilne kmetije na mešane, dopolnilne kmetije ter kmetije $\mathrm{v}$ opuščanju. Podatki o površinah zemlje v upravljanju kmečkih gospodarstev na Škofjeloškem so bili zbrani za populacijo kmečkih gospodarstev v okviru državnih statističnih 
popisov kmetijstva v letih 2000 in 2010 (Dernulc s sod. 2002; SURS 2010). Analize razlik aritmetičnih sredin zemlje v upravljanju kmečkih gospodarstev med letoma 2000 in 2010 oziroma med občinama oziroma po socio-ekonomskih tipih kmečkih gospodarstev so izvedene s t-testom in uporabo programa Statistical Package for the Social Sciences. Sprejemljiva stopnja tveganja znaša $5 \%$. Pri določitvi socio-ekonomskega tipa populacije kmečkih gospodarstev izhajamo (Kovačič 1996; Udovič, Kovačič in Kramarič 2006) iz zaposlitvenega statusa jedra KG. Zemljišča v upravljanju kmečkega gospodarstva so vsa zemljišča v uporabi, ki jih ima kmečko gospodarstvo v uporabi in jih delimo na gozd, nerodovitna zemljišča in kmetijska zemljišča. Kmetijska zemljišča zajemajo kmetijska zemljišča $v$ uporabi, kmetijska zemljišča v zaraščanju in druga neobdelana kmetijska zemljišča. Kmetijska zemljišča v uporabi obsega lastna in najeta kmetijska zemljišča $\mathrm{v}$ uporabi ter jih delimo na njive in vrtove, sadovnjake, vinograde ter travnike in pašnike (Dernulc s sod. 2002).

\section{Rezultati}

Na Škofjeloškem se je v obdobju 2000-2010 število kmečkih gospodarstev zmanjšalo za 7 \%, kar je dvakrat manj od povprečja za kmečka gospodarstva v Republiki Sloveniji (-14\%; Kutin Slatnar s sod. 2012) oziroma za več kot trikrat manj od povprečja EU-27 (-19,8\%, brez Malte in za obdobje 2003-2010 (Eurostat 2011). Zmanjšanje števila kmečkih gospodarstev je bilo med leti 2000 in 2010 pri občinah Škofja Loka $(-9 \%)$ in Gorenja vas-Poljane $(-5 \%)$ različno. Število komercialnih kmetij (čiste, mešane in dopolnilne kmetije) se je v občini Škofja Loka nekoliko povečalo (+ 4\%), v občini Gorenja vas-Poljane pa zmanjšalo (-4\%). Povečalo se je število dopolnilnih kmetij, zmanjšalo pa število mešanih kmetij in kmetij v opuščanju (preglednica 1). Kmetije v opuščanju so izstopale iz sektorja dvakrat hitreje na območju občine Škofja Loka kot na območju občine Gorenja vas-Poljane.

Večina zemlje na Škofjeloškem je v upravljanju kmečkih gospodarstev. V letu 2000 so kmečka gospodarstva na Škofjeloškem razpolagala s 69 \% površine ozemlja občin Škofja Loka in Gorenja vas-Poljane, v letu 2010 pa 66 \%. Povprečna površina zemljišč v upravljanju kmečkih gospodarstev je bila 19,2 ha zemljišč, od tega je bilo nekaj nad $61 \%$ gozda (12 ha), $38 \%$ kmetijskih zemljišč $(7,31$ ha) in $0,9 \%(0,17$ ha) nerodovitnih kmetijskih zemljišč. Med leti 2000 in 2010 se je površina nerodovitnih zemljišč statistično značilno zmanjšala pri populacij kmečkih gospodarstev, pri kmečkih gospodarstvih po občinah in pri vseh socio-ekonomskih tipih, razen pri mešanih kmetijah.

\subsection{Površina gozda v upravljanju kmečkih gospodarstev}

Leta 2010 so kmečka gospodarstva KG razpolagala z $122 \mathrm{~km}^{2}$ gozda, v letu 2000 pa z nekaj nad $3 \%$ manj. Povprečna površina gozda na kmečko gospodarstvo je bila v letu 2010, primerjalno z letom 2000, statistično značilno večja pri dopolnilnih kmetijah, medtem ko se je pri čistih in mešanih kmetijah in kmetijah v opuščanju zmanjšala (preglednica 1 ).

\subsection{Kmetijska zemljišča}

Kmečka gospodarstva so v letu 2000 v povprečju razpolagala z nekaj manj kot 7,2 ha kmetijskih zemljišč, kar je za petino več od povprečne vrednosti kmečkih gospodarstev v Sloveniji (5,9 ha; Dernulc s sod. 2002). Skupna površina kmetijska zemljišča v uporabi se je pri kmečkih gospodarstvih na Škofjeloškem med leti 2000 in 2010 zmanjšala za $7 \%$ predvsem zaradi zmanjšanja površin v upravljanju kmetij v opuščanju in ostarelih kmetijah ( -657 ha), medtem ko se je pri komercialnih kmetijah povečala (+289 ha). Povprečna površina kmetijskih zemljišč kmečkega gospodarstva se je statistično značilno povečala le pri kmečkih gospodarstvih iz občine Škofja Loka, in sicer predvsem na račun opuščanja kmetijske pridelave pri kmetijah v opuščanju (opustitev kmetijske pridelave) in zmanjšanja površine pri ostarelih kmetijah (preglednica 2).

Kmetijska zemljišča v zaraščanju so v letu 2000 obsegala $6,8 \%$ vseh kmetijskih zemljišč v upravljanju kmečkih gospodarstev oziroma 0,45 ha na kmečko gospodarstvo, kar je za 1,3-krat manj od slovenskega povprečja (Dernulc s sod. 2002), v letu 2010 pa se je njihova povprečna površina skoraj prepolovila. Povprečna površina kmetijske zemlje $\mathrm{v}$ zaraščanju se je statistično značilno zmanjšala pri kmečkih gospodarstvih iz občine Gorenja vas-Poljane, pri mešanih in dopolnilnih kmetijah ter ostarelih kmetijah (preglednica 2). Rezultat pripisujemo predvsem državnim pomočem vezanim na enoto površine. 


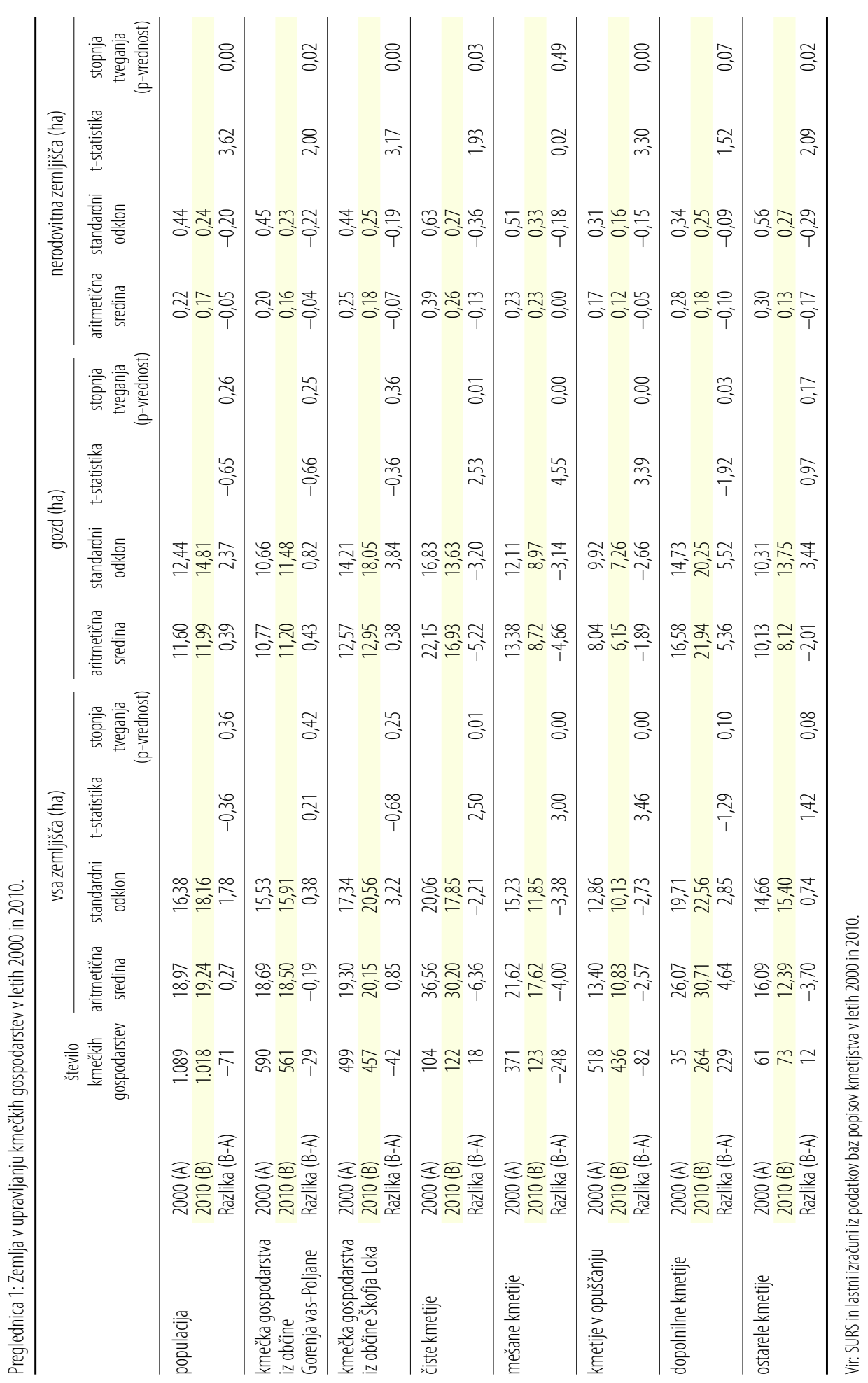




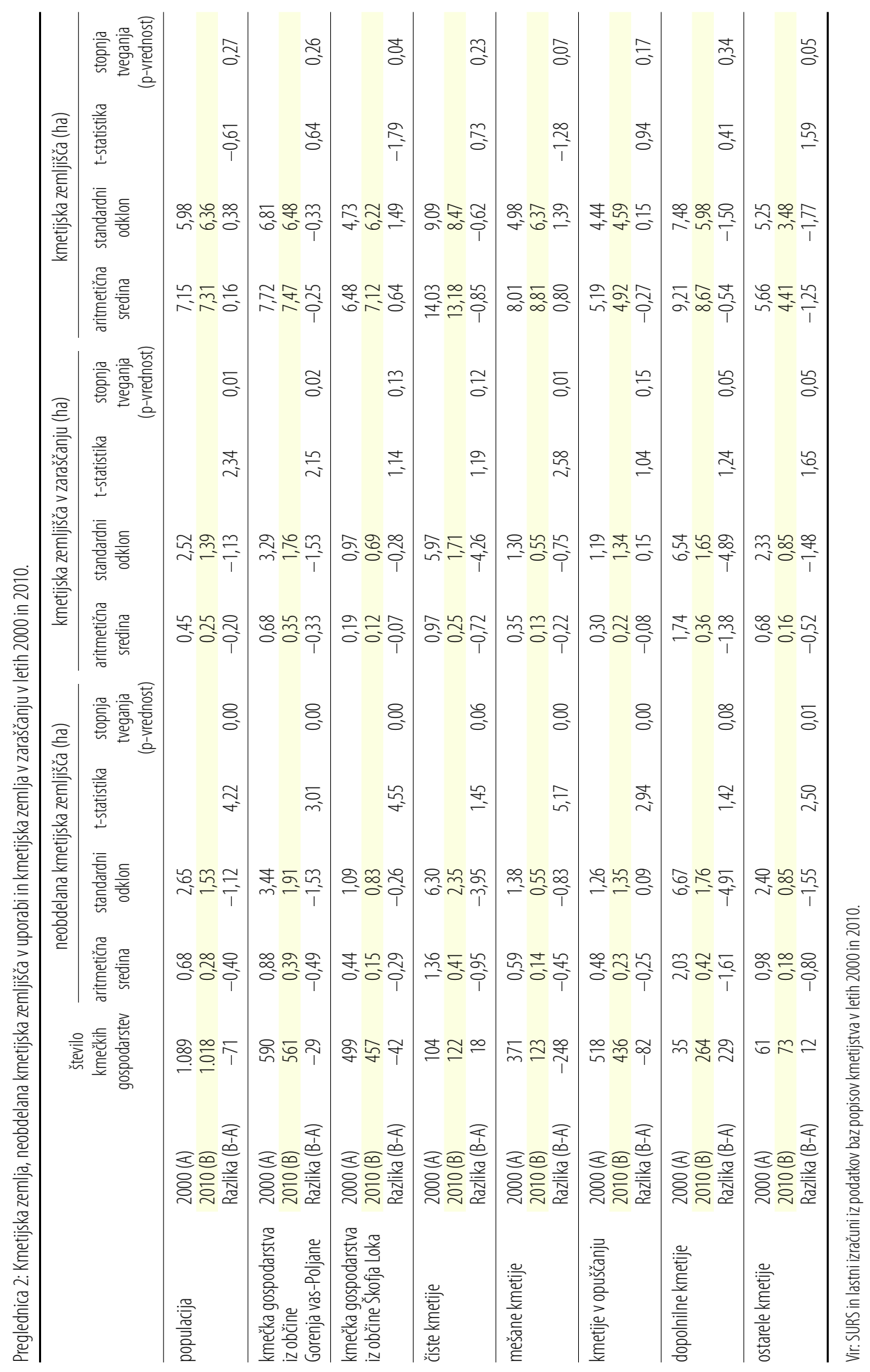




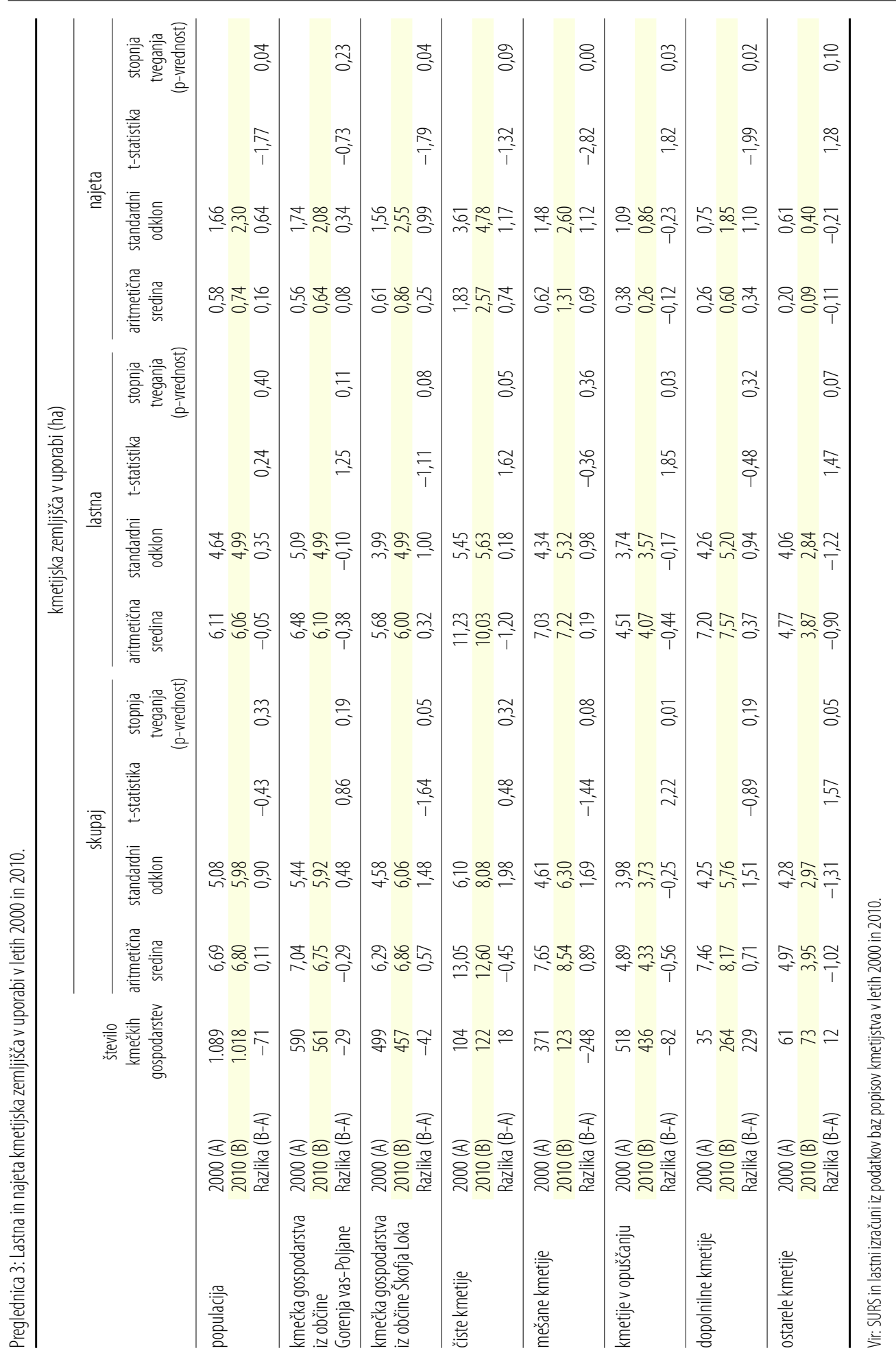


Površina nerodovitnih zemljišč v upravljanju kmečkih gospodarstev je bila v letu 2010, primerjalno z letom 2000, manjša pri populacij kmečkih gospodarstev, pri kmečkih gospodarstvih po občinah in po socio-ekonomskih tipih, razen pri mešanih kmetijah (preglednica 2).

Povprečna površina kmetijskega zemljišča v uporabi je v letu 2000 znašala 6,7 ha/KG, kar je za nekaj več kot $13 \%$ več od slovenskega povprečja (5,9 ha; Dernulc s sod. 2002). Med leti 2000 in 2010 se je povprečna površina KZU statistično značilno povečala za desetino pri kmečkih gospodarstvih iz občine Škofja Loka, predvsem na račun opuščanja kmetijske pridelave pri kmetijah v opuščanju in zmanjšanja površine kmetijskega zemljišča $\mathrm{v}$ uporabi pri ostarelih kmetijah in kmetijah v opuščanju (preglednica 3). Večja povprečna površina najetega kmetijskega zemljišča v uporabi v letu 2010, primerjalno z letom 2000, pri populaciji kmečkih gospodarstev izhaja predvsem iz večje površine najetih kmetijskih zemljišč v uporabi pri kmečkih gospodarstvih iz občine Škofja Loka oziroma večje površine najetih kmetijskih zemljišč v uporabi komercialnih kmetij, medtem ko se je povprečna najeta površina kmetijskih zemljišč v uporabi zmanjšala pri nekomercialnih kmetijah (preglednica 3). Kmečka gospodarstva iz občine Škofja Loka so razpolagala s skoraj 6-krat večjo površino njiv (1,8 ha/kmečkih gospodarstvo), kmečkih gospodarstev iz občine Gorenja vas-Poljane pa z četrtino večjo površino trajnih travnikov in pašnikov.

Med letoma 2000 in 2010 so pri kmečkih gospodarstvih nastale tudi spremembe v površini kmetijskih zemljišč $\mathrm{v}$ uporabi po razredih kmetijskih zemljišč v uporabi $\mathrm{v}$ smeri polarizacije rasti velikosti kmečkih gospodarstev po površini kmetijskih zemljišč v uporabi, in sicer v dve smeri: skupina relativno velikih komercialnih kmetij (kmetijska zemljišča v uporabi nad 15 ha) in skupina manjših kmetij (kmetijska zemljišča v uporabi 3-5 ha). Razloge za navedeno pripisujemo poleg opuščanja kmetijske pridelave pri manjših kmetijah po površini kmetijskih zemljišč $\mathrm{v}$ uporabi tudi relativnemu ohranjanju kmetijske pridelave pri posameznih malih kmetijah, ki so pretežno samooskrbne (3-5ha kmetijskih zemljišč v uporabi) in povečevanju velikosti kmetije in koriščenju ekonomije obsega pri preostalih kmetijah v smeri večjih kmetij po površini kmetijskih zemljišč v uporabi (nad 15 ha kmetijskih zemljišč v uporabi). Polarizacija je nekoliko izrazitejša pri kmečkih gospodarstvih iz občine Škofja Loka.

\section{Sklep}

Večino kmetijskih zemljišč na Škofjeloškem so v letih 2000 in 2010 v upravljala kmetijska gospodarstva. Povprečna površina zemlje (gozd, kmetijska zemlja in nerodovitna zemljišča) kmečkega gospodarstva na Škofjeloškem se je statistično neznačilno povečala, medtem ko se je skupna površina zemlje u upravljanju kmečkih gospodarstev zmanjšala, predvsem na račun zmanjšanja površine zemlje v upravljanju kmetij v opuščanju (manjše, pretežno samooskrbne kmetije). Število kmetij v opuščanju in mešanih kmetij se je zmanjšalo, povečalo se je število dopolnilnih kmetij. Za preživetje dela dopolnilnih kmetij je med leti 2000 in 2010 pomemben tudi gozd s predelavo lesa v okviru dopolnilne dejavnosti na kmetiji. Spremembe so bile izrazitejše na območju $z$ bolj razvito industrijo in boljšimi naravnimi danostmi za kmetijsko predelavo. Število čistih kmetij se navidezno ohranja predvsem zaradi upokojevanja gospodarjev čistih kmetov, kot tudi tistih $\mathrm{z}$ nekmetijskimi zaposlitvami.

Strukturne spremembe med leti 2000 in 2010 se pri kmečkih gospodarstvih med območjema z različnimi naravnimi danostmi za kmetijsko pridelavo in gospodarsko razvitostjo razlikujejo v smeri in obsegu sprememb. Na območju z omejenimi možnostmi za kmetijsko pridelavo so državne pomoči vezane na površino kmetijskega zemljišča v uporabi preprečile zaraščanje kmetijske zemlje, zmanjšala se je tudi površina nerodovitnih zemljišč, medtem ko se je površina neobdelanih kmetijskih zemljišč zmanjšala na obeh območjih in pri vseh socio-ekonomskih tipih. Strukturne spremembe, ki se odražajo z opuščanjem kmetijske pridelave pri manjših kmetijah in povečevanju površin pri preostalih (predvsem najem kmetijskih zemljišča v uporabi) so relativno počasnejše od slovenskega povprečja in izrazitejše pri kmečkih gospodarstvih na območju z boljšimi naravnimi danostmi za kmetijsko pridelavo. Opazna je smer polarizacije rasti velikosti kmečkih gospodarstev po površini kmetijskih zemljišč v uporabi, in sicer v dveh smereh: skupina relativno velikih komercialnih kmetij (kmetijska zemljišča v uporabi nad $15 \mathrm{ha}$ ) in skupina manjših, pretežno samooskrbnih kmetij (kmetijska zemljišča v uporabi 3-5 ha). Rast površine kme- 
tijskih zemljišč v uporabi izvira predvsem iz večjega obsega najetih kmetijskih zemljišč v uporabi pri komercialnih kmetijah, medtem ko se površina njihove lastnih kmetijskih zemljišč v uporabi ni povečala.

\section{Literatura}

Glej angleški del prispevka. 
